\title{
KEANEKARAGAMAN JENIS BURUNG DI HUTAN RAKYAT PEKON KELUNGU KECAMATAN KOTAAGUNG KABUPATEN TANGGAMUS
}

\author{
(BIRD DIVERSITY IN COMMUNITY FOREST KELUNGU VILLAGE \\ KOTAAGUNG SUB DISTRICT TANGGAMUS DISTRICT)
}

\author{
Maya Adelina ${ }^{1)}$, Sugeng P. Harianto ${ }^{1)}$, dan Nuning Nurcahyani ${ }^{2)}$ \\ 1) Jurusan Kehutanan Fakultas Pertanian Universitas Lampung, \\ 2) Jurusan Biologi Fakultas Matematika dan IPA Universitas Lampung, \\ Jl. Soemantri Brojonegoro no.1 Bandar Lampung \\ E-mail : Maya.adelina.27@gmail.com No.Telepon : 085766809908
}

\begin{abstract}
ABSTRAK
Burung adalah salah satu jenis satwaliar yang banyak dimanfaatkan oleh manusia (Darmawan, 2006). Kondisi ekosistem alami yang terus mengalami tekanan menyebabkan perlu dilakukan berbagai upaya konservasi burung. Upaya konservasi juga perlu dilakukan di hutan rakyat. Salah satu hutan rakyat yang teridentifikasi sebagai habitat burung adalah hutan rakyat Pekon Kelungu. Hutan rakyat selain memproduksi kayu, juga berfungsi sebagai tempat perlindungan dan pelestarian keanekaragaman seluruh satwa termasuk burung. Penelitian ini perlu dilakukan karena belum adanya data mengenai keanekaragaman jenis burung di areal tersebut. Penelitian ini bertujuan untuk mengetahui keanekaragaman jenis burung yang terdapat di hutan rakyat Pekon Kelungu, Kecamatan Kotaagung, Kabupaten Tanggamus, Provinsi Lampung. Penelitian dilakukan pada bulan Juni 2015 dengan menggunakan metode pengamatan langsung (point count) pada tiga titik di lokasi pengamatan yaitu: perbatasan antara hutan rakyat dengan pemukiman (PC 1), antara Hutan Rakyat dengan hutan lindung (PC 2), dan jalur sempadan sungai (PC 3) dengan 3 kali pengulangan. Hasil penelitian ditemukan 27 spesies burung dari 16 famili (3018 individu). Pada tipe habitat I memiliki indeks keanekaragaman shannon $\left(H^{\prime}=1,701\right)$ pada Tipe habitat II yaitu $\left(H^{\prime} 2,630\right)$, sedangkan tipe habitat III $\left(\mathrm{H}^{\prime}=2,58\right)$. Kriteria indeks Shannon Wiener tersebut tergolong sedang. Indeks kesamarataan $\mathrm{J}$ pada tipe habitat $\mathrm{I}(\mathrm{J}=0,578)$ tergolong labil, pada tipe habitat II $(\mathrm{J}=0,817)$ dan pada tipe habitat III $(\mathrm{J}=0,801)$ tergolong stabil. Indeks kesamaan spesies (PC I dan II $=0,773)$, (PC I dan III = 0,773) kategori tinggi, $(\mathrm{PC}$ II dan III = 1) kategori sangat tinggi.
\end{abstract}

Kata kunci: burung, keanekaragaman jenis, hutan rakyat, dan Pekon Kelungu

\section{ABSTRACT}

Bird is one of the wild animals that often utilized by people. Since the condition of natural ecosystems pressed continually, the conservation efforts for bird also need to be done. Qece 4ionservation efforts also need to be done in other areas, one of them is at the community forest. One of the community forest identified as bird habitats is the community forest in Kelungu Village. Besides as timber production, community forest also serve as protection and preservation place of birds diversity. This research necessary because of the lack the data about the diversity of bird species in this area. The purposes of this research was to determine the diversity of bird species in the community forest Kelungu Village, Kotaagung Subdistrict, Tanggamus, Lampung Province. The research was conducted in June 2015 using a direct observation method (point count) at three points of the observation location that were the border between the community forest and the settlement (PC 1), between the palm garden and 
protected forest (PC 2), and river border lines (PC 3) with 3 repetitions. The results showed there were 27 bird species from 16 families (3018 individuals). The first habitat type has $\left(H^{\prime}=1,701\right)$ Shannon Weiner diversity index. The second habitat type has $\left(H^{\prime} 2,630\right)$ then the third habitat type has $\left(H^{\prime}=2,58\right)$ were classified moderate. Evenness index in first habitat $(J=$ $0,578)$ was classified relatively, in second habitat $(J=0,817)$ and third habitat $(J=0,801)$ were classified stable. Similarity index (PC I and II =0,773) and (PC I and III =0,773) were classified high category, (PC II and III = 1) very high category.

Key words: birds, biodiversity, community forest, and Kelungu Village

\section{PENDAHULUAN}

Burung adalah salah satu jenis satwaliar yang banyak dimanfaatkan oleh manusia sebagai bahan makanan, binatang peliharaan, pemenuhan kebutuhan ekonomi, dan estetika. Jumlah penduduk yang meningkat dan tingginya pemanfaatan jenis burung oleh manusia, mengakibatkan terjadinya tekanan terhadap spesies dan habitat alami burung. Hilangnya vegetasi menyebabkan juga hilangnya sumber pakan bagi burung (Firdaus, Setiawan, dan Rustiati, 2014). Manfaat burung bagi manusia baik secara langsung maupun tidak langsung berdampak terhadap kelestarian spesies burung (Darmawan, 2006). Penelitian tentang burung merupakan hal yang sangat penting karena burung bersifat dinamis dan mampu menjadi indikator perubahan lingkungan yang terjadi pada daerah tersebut (Bibby, Neil, dan David, 2004). Kondisi ekosistem alami yang terus mengalami tekanan menyebabkan perlu dilakukan upaya-upaya konservasi (Holmes dan Rombang, 2001).

Keberadaan burung di Hutan Rakyat Pekon Kelungu, Kecamatan Kotaagung, Kabupaten Tanggamus belum diketahui secara pasti tingkat keanekaragamannya. Oleh karena itu, perlu dilakukan penelitian mengenai keanekaragaman jenis burung di Hutan Rakyat Pekon Kelungu, agar diperoleh data keanekaragaman jenis burung dalam upaya konservasi burung.

\section{METODE PENELITIAN}

Penelitian ini dilaksanakan pada bulan Juni 2015 di Hutan Rakyat Pekon Kelungu, Kecamatan Kotaagung, Kabupaten Tanggamus dengan alat yang digunakan berupa jam digital, Global Positioning System (GPS), binokuler, lembar pengamatan/ tally shett, dan buku panduan lapangan burung-burung di Sumatera, Jawa, Bali, dan Kalimantan karangan (Mac Kinnon, Philipps, dan Van Balen, tahun 1998). Bahan yang digunakan adalah spesies burung yang ada di lokasi penelitian. Metode pengumpulan data dalam penelitian ini yaitu orientasi di lapangan untuk mengenal areal penelitian, kondisi di lapangan dan titik pengamatan untuk memudahkan pengamatan. Pengamatan burung dilakukan dengan menggunakan metode pengamatan secara langsung yaitu menggunakan metode Point Count Kondisi umum areal pengamatan diamati dengan metode rapid assessment untuk mendapatkan gambaran secara umum tipe vegetasi (Brower, Jerrold, and Von ende, 1990).

Peta lokasi penempatan titik pengamatan burung di Hutan Rakyat Pekon Kelungu Kecamatan Kotaagung Kabupaten Tanggamus disajikan pada Gambar 1. 


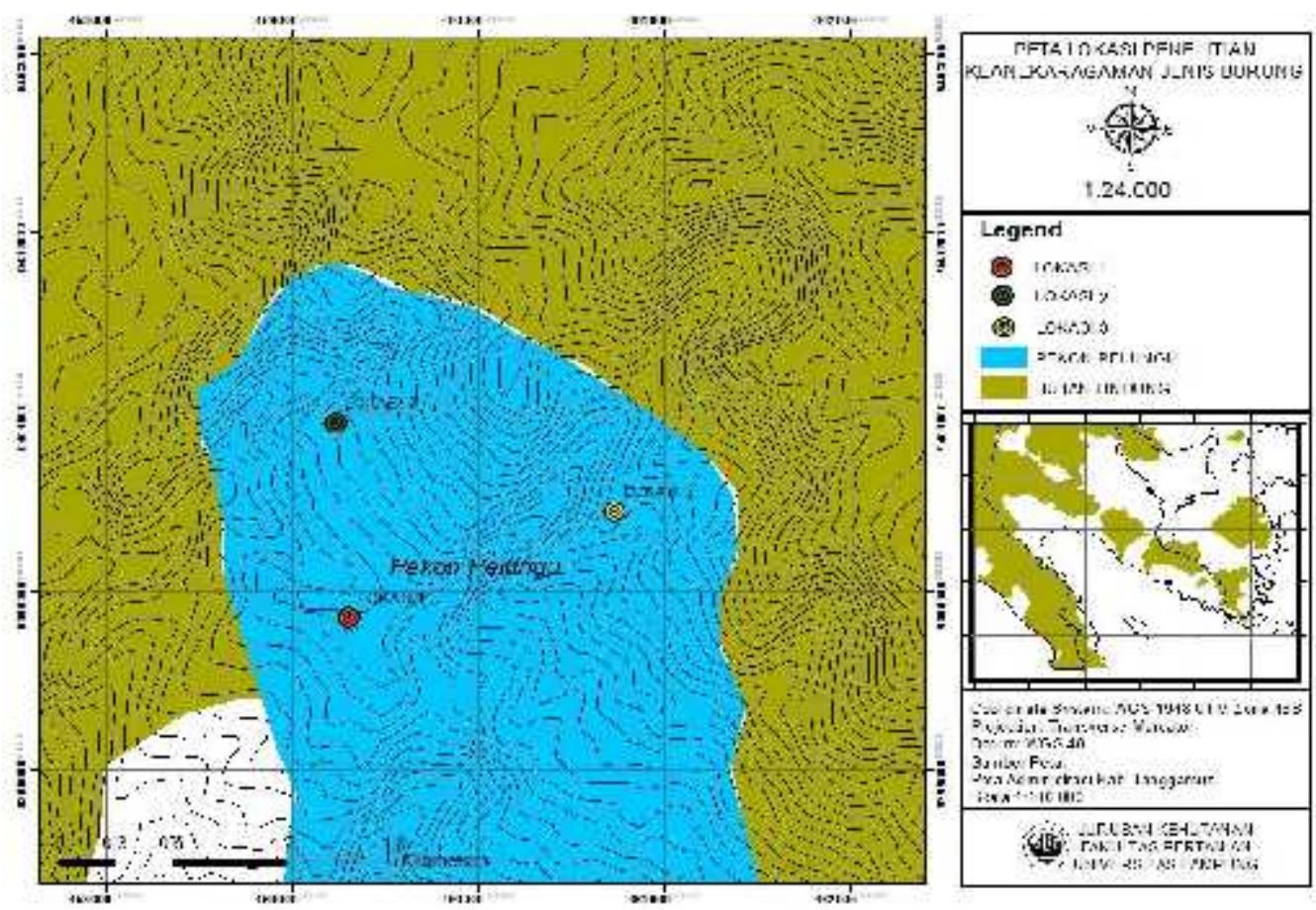

Gambar 1. Peta lokasi penempatan titik pengamatan burung di Hutan Rakyat Pekon Kelungu Kecamatan Kotaagung Kabupaten Tanggamus menggunakan metode titik hitung (Point Count) dengan skala 1:24.000 (Pergola, 2015).

Analisis data dapat dilakukan dengan beberapa cara yaitu:

1. Analisis indeks keanekaragaman burung

Keanekaragaman burung dihitung dengan menggunakan indeks keanekaragaman (Diversity index) Shannon-Wienner (Odum, 1971; Fachrul, 2007), dengan rumus sebagai berikut:

$$
H^{\prime}=-\sum P i \ln (P i) \text {, dimana } P i=(n i / N)
$$

Keterangan:

$H^{\prime}=$ Indeks keanekaragaman Shannon-Wiener,

ni $=$ Jumlah individu jenis ke-i

$\mathrm{N}=$ Jumlah individu seluruh jenis

Kriteria nilai indeks keanekaragaman Shannon-Wiener $\left(H^{\prime}\right)$

$\bar{H} \leq 1 \quad$ : keanekaragaman rendah,

$1<\bar{H}<3$ : Keanekaragaman sedang

$H \geq 3 \quad$ : Keanekaragaman tinggi

2. Analisis indeks kesamarataan

Indeks kesamarataan (Evenness index) diperoleh dengan menggunakan rumus (Daget, 1976;

Solahudin, 2003):

$$
J=H^{\prime} / H \max \text { atau } \mathrm{j}=-\sum p i \ln (p i) / \ln (S)
$$

Keterangan:

$J=$ Indeks kesamarataan,

$S=$ Jumlah jenis.

Kriteria indeks kesamarataan $(J)$ :

$0<J \leq 0,5 \quad$ : Komunitas tertekan,

$0,5<J \leq 0,75$ : Komunitas labil,

$0,75<J \leq 1 \quad$ : Komunitas stabil. 
3. Analisis indeks kesamaan spesies antar habitat

Indeks kesamaan (Similarity index) dihitung dengan menggunakan rumus (Odum, 1993; Indriyanto, 2006).

$$
\text { IS }=2 \mathrm{C} /(\mathrm{A}+\mathrm{B}
$$

Keterangan :

$\mathrm{A}=$ Jumlah spesies dalam komunitas A

$\mathrm{B}=$ Jumlah spesies dalam komunitas B

$\mathrm{C}=$ jumlah spesies yang sama pada kedua komunitas

Kriteria kesamaan komunitas (IS): (Odum, 1993; Pamungkas dan Dewi, 2015).
$1-30 \%$
: Kategori rendah
$31-60 \%$
: Kategori sedang
$61-91 \%$
: Kategori tinggi
$>91 \%$
: Kategori sangat tinggi

4. Analisis deskriptif

Analisis deskriptif digunakan dalam pemanfaatan habitat dan vegetasi oleh burung dan diuraikan secara deskriptif berdasarkan hasil pengamatan yang dilakukan.

\section{HASIL DAN PEMBAHASAN}

\section{Keanekaragaman spesies burung}

Berdasarkan hasil penelitian yang telah dilakukan di Pekon Kelungu Kecamatan Kotaagung, ditemukan 27 spesies burung $(\mathrm{N}=3018)$ berasal dari 16 famili disajikan pada Tabel 1.

Tabel 1. Spesies burung yang ditemukan pada penelitian keanekaragaman jenis burung di Hutan Rakyat Pekon Kelungu Kecamatan Kotaagung Kabupaten Tanggamus Juni 2015.

\begin{tabular}{clllrrrr}
\hline \multirow{2}{*}{ No } & \multirow{2}{*}{ Nama Spesies } & \multicolumn{1}{c}{ Nama ilmiah } & Famili & \multicolumn{2}{c}{ Stasiun } & \multirow{2}{*}{ Jumlah } \\
\cline { 5 - 6 } & & Pc 1 & Pc 2 & Pc 3 & \\
\hline 1 & Elang Hitam* & Ictinaetus malayensis & Accipitridae & 2 & 4 & 1 & 7 \\
2 & Elang Bondol* & Haliastur indus & Accipitridae & 0 & 1 & 4 & 5 \\
3 & Perkutut Jawa & Geopelia striata & Columbidae & 25 & 45 & 47 & 117 \\
4 & Tekukur Biasa & Streptopelia chinensis & Columbidae & 68 & 108 & 47 & 223 \\
5 & Puyuh Batu & Coturnix chinensis & Phasianidae & 26 & 15 & 16 & 57 \\
6 & Walet Sapi & Collocalia esculenta & Apodidae & 223 & 179 & 330 & 732 \\
7 & Layang-Layang & Delichon dasypus & Hirundinidae & 126 & 157 & 159 & 442 \\
& Rumah & & & & & \\
8 & Cucak Kutilang & Pycnonotus melanicterus & Pycnonotidae & 60 & 86 & 78 & 224 \\
9 & Cucak Kuning & Pycnonotus aurigaster & Pycnonotidae & 91 & 67 & 114 & 272 \\
10 & Madu Pengantin* & Nectarinia sperata & Nectariniidae & 5 & 16 & 32 & 53 \\
11 & Perenjak Jawa & Prinia familiaris & Silviidae & 48 & 55 & 48 & 151 \\
12 & Kucica Hutan & Copsychus malabaricus & Timaliidae & 3 & 20 & 23 & 46 \\
13 & Kecici Lurik & Locustella lanceolata & Silviidae & 3 & 33 & 48 & 84 \\
14 & Kacamata Topi & Zosterops atricapilla & Zosteropidae & 37 & 32 & 28 & 97 \\
& Hitam & & & & & \\
15 & Gereja & Passer montanus & Ploceidae & 37 & 0 & 0 & 37 \\
16 & Bondol Haji & Lonchura maja & Ploceidae & 33 & 4 & 3 & 40 \\
17 & Bondol Peking & Lonchura punctulata & Ploceidae & 56 & 23 & 4 & 83 \\
18 & Kecici Belalang & Locustella certhiola & Silviidae & 13 & 14 & 36 \\
\hline
\end{tabular}


Tabel 1. Lanjutan ...

\begin{tabular}{|c|c|c|c|c|c|c|c|}
\hline \multirow{2}{*}{ No } & \multirow{2}{*}{ Nama Spesies } & \multirow{2}{*}{ Nama ilmiah } & \multirow{2}{*}{ Famili } & \multicolumn{3}{|c|}{ Stasiun } & \multirow{2}{*}{ Jumlah } \\
\hline & & & & Pc 1 & Pc 2 & Pc 3 & \\
\hline 19 & Gelatik Batu & Parus major & Paridae & $\overline{0}$ & 10 & 24 & 34 \\
\hline 20 & Kacamata Biasa & Zosterops palpebrosus & Zosteropidae & 6 & 19 & 28 & 53 \\
\hline 21 & Kacamata Gunung & Zosterops montanus & Zosteropidae & 0 & 2 & 15 & 17 \\
\hline 22 & Madu Sriganti* & Nectarinia jugularis & Nectariniidae & 0 & 29 & 18 & 47 \\
\hline 23 & Sikatan Ninon & Eumias indigo & Muscicapidae & 0 & 8 & 18 & 26 \\
\hline 24 & $\begin{array}{l}\text { Takur Warna } \\
\text { Warni }\end{array}$ & Megalaima rafflesii & Capitonidae & 0 & 10 & 16 & 26 \\
\hline 25 & Berkecet Biri & Erithacus cyane & Turdidae & 0 & 3 & 14 & 17 \\
\hline 26 & Kicut Kerbau & Motacilla flava & Motacillidae & 0 & 18 & 39 & 57 \\
\hline \multirow[t]{2}{*}{27} & Bondol Jawa & $\begin{array}{l}\text { Lonchura } \\
\text { leucogastroides }\end{array}$ & Ploceidae & 8 & 0 & 0 & 8 \\
\hline & & & Jumlah & 870 & 958 & 1190 & 3018 \\
\hline
\end{tabular}

Keterangan :

PC 1 : Perbatasan antara hutan rakyat dan pemukiman

PC 2 : Perbatasan antara hutan rakyat dengan hutan lindung

PC 3 : Sepanjang jalur sungai

* : : Spesies yang dilindungi berdasarkan Peraturan Pemerintah No.7 tahun 1999 tentang pengawetan jenis tumbuhan dan satwa (Departemen Kehutanan, 1999).

Tabulasi hasil perhitungan indeks keanekaragaman spesies burung di Pekon Kelungu Kecamatan Kotaagung disajikan pada Tabel 2.

Tabel 2. Indeks keanekaragaman dan kesamarataan spesies burung pada penelitian keanekaragaman jenis burung di Hutan Rakyat Pekon Kelungu Kecamatan Kotaagung Kabupaten Tanggamus Juni 2015

\begin{tabular}{llll}
\hline $\begin{array}{l}\text { Titik Stasiun (Point } \\
\text { count) }\end{array}$ & $\begin{array}{l}\text { Jumlah } \\
\text { Spesies }\end{array}$ & $\begin{array}{l}\text { Indeks } \\
\text { Keanekaragaman }\end{array}$ & $\begin{array}{l}\text { Indeks } \\
\text { Kesamarataan }\end{array}$ \\
\hline PC 1 & 19 & $1,701 *$ & $0,578^{*}$ \\
PC 2 & 25 & $2,63 *$ & $0,817 * * *$ \\
PC 3 & 25 & $2,58 *$ & $0,801 * * *$ \\
\hline
\end{tabular}

Keterangan:

* : Indeks keanekaragaman sedang

** : Indeks kesamarataan menunjukkan komunitas labil

*** : Indeks kesamarataan menunjukkan komunitas stabil

Tabulasi hasil perhitungan indeks kesamaan (Similarity index) di Pekon Kelungu Kecamatan Kota agung disajikan pada Tabel 3.

Tabel 3. Indeks kesamaan spesies antar habitat pada penelitian keanekaragaman jenis burung di Hutan Rakyat Pekon Kelungu Kecamatan Kotaagung Kabupaten Tanggamus Juni 2015

\begin{tabular}{|c|c|c|c|}
\hline Stasiun (Point count) & PC 1 & PC 2 & PC 3 \\
\hline$\overline{\mathrm{PC}} 1$ & - & $0,773 *$ & $0,773 *$ \\
\hline PC 2 & & - & $1 * *$ \\
\hline PC 3 & & & - \\
\hline
\end{tabular}

Keterangan:

* = Kategori tinggi

$* *$ = Kategori sangat tinggi 
Tabulasi jenis vegetasi yang terdapat di Pekon Kelungu, Kecamatan Kotaaung, Kabupaten Tanggamus dapat disajikan pada Tabel 4.

Tabel 4. Jenis vegetasi pada penelitian keanekaragaman jenis burung di Hutan Rakyat Pekon Kelungu Kecamatan Kotaagung Kabupaten Tanggamus Juni 2015

\begin{tabular}{clll}
\hline No & \multicolumn{1}{c}{ Nama Lokal } & \multicolumn{1}{c}{ Nama Ilmiah } & \multicolumn{1}{c}{ Famili } \\
\hline 1 & Jengkol & Pithecellobium lobatum & Mimosaceae \\
2 & Manggis & Garcinia mangostana & Gutiferae \\
3 & Durian & Durio zibetinus & Bombacacae \\
4 & Petai & Parkia speciosa & Mimosaceae \\
5 & Cempaka & Michelia champaca & Magnoliaceae \\
6 & Kakao & Theobroma cacao & Malvaceae \\
7 & Sengon & Paraserianthes falcataria & Mimosaceae \\
8 & Duku & Lansium domesticum & Meliaceae \\
9 & Pala & Myristica fragrans & Myristicaceae \\
10 & Mangga & Mangifera indica & Anacardiaceae \\
11 & Rambutan & Nephelium lappaceum & Sapindaceae \\
12 & Jati & Tectona grandis & Verbenaceae \\
13 & Tangkil & Gnetum genemon & Gnetaceae \\
14 & Akasia & Acacia auricuriformis & Mimosaceae \\
15 & Nangka & Artocarpus integra & Moraceae \\
16 & Kemiri & Aleurites moluccana & Euphorbiaceae \\
17 & Kelapa & Cocos nucifera & Arecaceae \\
18 & Cempedak & Autocarpus champeden & Moraceae \\
19 & Asam Jawa & Tamarindus indica & Caesalpiniaceae \\
\hline
\end{tabular}

a. Keanekaragaman spesies burung

Berdasarkan hasil pengamatan burung di Pekon Kelungu Kecamatan Kotaagung Kabupaten Tanggamus diperoleh keanekaragaman jenis burung yang berbeda antara tiga stasiun (point count) pada Tabel 2, dan secara keseluruhan memiliki tingkat keanekaragaman sedang $(1<\bar{H}<3)($ Gambar 2$)$.

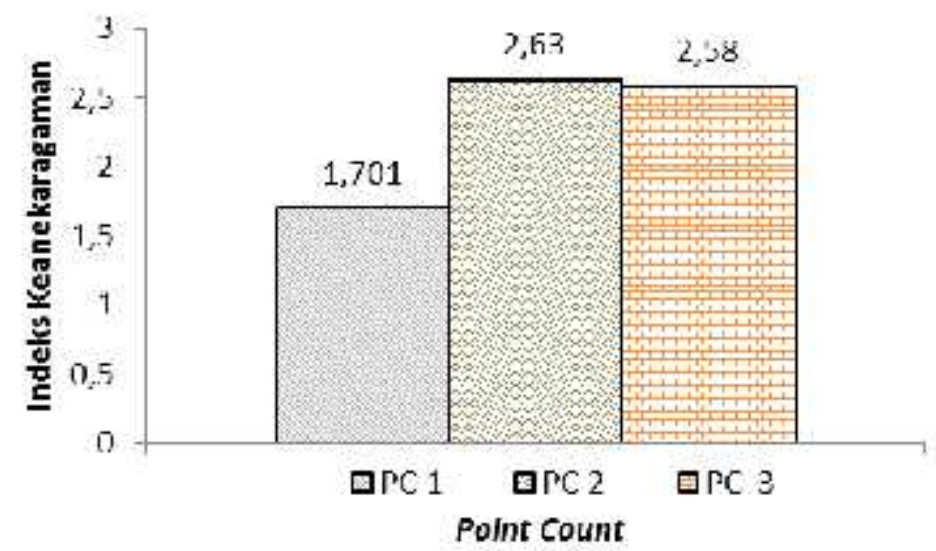

Gambar 2. Histogram indeks keanekaragaman (H') burung pada tiga stasiun (Point count) pada penelitian keanekaragaman jenis burung di Hutan Rakyat Pekon Kelungu Kecamatan Kotaagung Kabupaten Tanggamus Juni 2015

Berdasarkan perhitungan indeks keanekaragaman pada seluruh stasiun diperoleh data pada stasiun satu memiliki nilai keanekaragaman yaitu 1,701 dengan 19 spesies, stasiun dua 
memiliki nilai keanekaragaman 2,63 dengan 25 spesies, dan stasiun tiga memiliki nilai keanekaragaman 2,58 dengan 25 spesies, dapat dilihat pada Tabel 2. Hasil penelitian tersebut menunjukkan bahwa stasiun dua memiliki tingkat keanekaragaman paling tinggi, sedangkan pada stasiun satu memiliki tingkat keanekaragaman paling rendah. Hal ini disebabkan pada stasiun satu yang terletak di antara hutan rakyat berbatasan dengan pemukiman dimana pohon-pohon yang kurang rapat yang membuat ketersedian sumber pakan bagi burung tidak tercukupi dan juga interaksi manusia pada daerah pemukiman membuat ekosistem alami bagi burung mengalami tekanan, karena kondisi habitat sangat berpengaruh terhadap tinggi rendahnya kenakeragaman jenis burung (Simanjutak, Nurdjali, dan Siahan, 2013).

Menurut Handari (2012), tingginya jumlah spesies burung pada habitat hutan diduga berkaitan dengan ketersediaan pakan yang cukup melimpah. Selain untuk melihat keanekaragaman spesies burung, indeks keanekaragaman juga dapat digunakan untuk mengukur stabilitas komunitas, yaitu kemampuan komunitas untuk menjaga kondisi tetap stabil meskipun ada gangguan terhadap komponen-komponennya (Soegianto, 1994; Indriyanto, 2006).

\section{b. Indeks Kesamarataan}

Nilai indeks kesamarataan spesies menggambarkan kestabilan suatu komunitas, yaitu bila angka nilai kesamarataan lebih dari 0,75 maka dikatakan komunitas stabil. Semakin kecil nilai indeks kesamarataan spesies maka penyebaran spesies tidak merata, artinya dalam komunitas ini tidak ada spesies yang mendominasi sehingga kemungkinan tidak ada persaingan dalam mencari kebutuhan untuk hidup. Nilai indeks kesamarataan pada hutan rakyat Pekon Kelungu pada stasiun satu memiliki nilai indeks kesamarataan 0,578 sehingga dapat dikatakan memiliki komunitas labil dengan nilai indeks kesamarataan $0,5<J \leq 0,75$. Stasiun dua memiliki nilai indeks kesamarataan 0,817 dan stasiun tiga memiliki nilai indeks kesamarataan 0,801 sehingga dapat dikatakan memiliki komunitas stabil dengan nilai indeks kesamarataan $(0,75<J \leq 1)$ disajikan pada Gambar 3 .

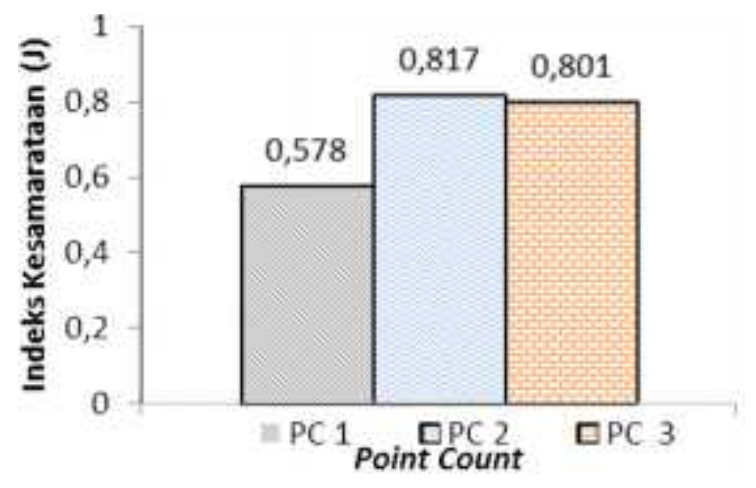

Gambar 3. Histogram indeks kesamarataan (J') burung pada tiga Stasiun (Point count) pada penelitian keanekaragaman jenis burung di Hutan Rakyat Pekon Kelungu Kecamatan Kotaagung Kabupaten Tanggamus Juni 2015.

Nilai indeks kemerataan pada stasiun satu yang terletak di Hutan Rakyat dekat dengan pemukiman menunjukkan nilai indeks kemerataan terkecil, hal ini disebabkan jumlah spesies penyusun pada stasiun satu lebih sedikit dibandingakan pada stasiun dua dan stasiun tiga. Nilai indeks kesamarataan pada stasiun dua dan stasiun tiga di atas 0,75 disebabkan kelimpahan spesies pada hutan rakyat tersebut tersebar secara merata atau populasi masingmasing spesies tidak ada yang mendominasi setara terhadap jumlah spesies, jika kelimpahan spesies tersebar secara merata maka kekayaan spesiesnya dianggap tinggi. 


\section{c. Tingkat kesamaan spesies (Similarity Index)}

Kesamaan spesies burung antar habitat di Pekon Kelungu Kecamatan Kotaagung Kabupaten Tanggamus dapat dilihat pada Tabel 3. Nilai indeks kesamaan pada tiga stasiun penelitian memiliki nilai mendekati angka satu, indeks kesamaan yang mendekati angka satu adalah indeks kesamaan dari stasiun satu dan stasiun dua yaitu 0.77 , stasiun satu dengan stasiun tiga yaitu 0.77 , sedangkan stasiun dua dengan stasiun tiga yaitu satu yang artinya dalam stasiun pengamatan ini terdapat banyak spesies yang sama. Menurut Rohiyan, Setiawan dan Rustiati (2014) tingginya jumlah spesies yang dapat hidup di suatu komunitas menunjukkan bahwa komunitas tersebut memberikan peranan baik bagi keberadaan burung untuk mencari pakan, bersarang dan berlindung dari predator. Vegetasi merupakan komponen habitat burung yang penting dalam menunjang kehidupan (Martin, Harianto, dan Dewi, 2012). Menurut Paerman (2002) habitat merupakan tempat makhluk hidup berada secara alami. Nilai indeks kesamaan yang tinggi disebabkan daya jelajah burung yang cukup luas sehingga burung mampu hidup di berbagai habitat dan penggunaan ruang dalam habitat yang hampir sama walaupun kedua stasiun ini memiliki kondisi yang berbeda.

Nilai indeks kesamaan yang paling rendah adalah di stasiun satu dan stasiun dua, stasiun satu dan stasiun tiga yaitu sama-sama memiliki nilai 0,77 . Hal ini diduga karena habitat stasiun satu memiliki kondisi vegetasi yang berbeda dengan stasiun dua dan tiga, sehingga memiliki komposisi spesies yang juga berbeda. Pada stasiun satu vegetasinya tidak terlalu rapat, hal ini diduga mempengaruhi perkembangbiakan bagi burung tersebut. Berbeda dengan lokasi pengamatan pada stasiun dua dan tiga yang habitatnya memberikan perlindungan, sumber pakan dan kebutuhan bagi burung tersebut (Tabel 3).

\section{Peran Habitat Bagi Burung}

Satwa membutuhkan tempat yang dapat menjamin segala keperluan hidupnya, baik makanan, air, tempat berkembang biak, berlindung, maupun tempat pengasuhan anak (Handari, 2012). Habitat yang baik di dalamnya mengandung bermacam-macam sumber pakan, memungkinkan memiliki jenis burung yang banyak. Dengan makin banyak jenis pohon berarti akan tercipta banyak relung ekologi yang memungkinkan berbagai jenis burung dapat hidup secara bersama (Setiawan, Alikodra, Gunawan dan Darnaedi, 2006). Kehadiran burung merupakan penyeimbang lingkungan dalam komponen ekosistem, karena burung memiliki peran sebagai satwa pemangsa puncak, satwa pemecah biji, satwa penyerbuk, dan satwa predator hama (Ramdhani, 2008).

Hutan Rakyat Pekon Kelungu Kecamatan Kotaagung Kabupaten Tanggamus mempunyai peranan yang cukup penting untuk tempat bertengger bagi burung pemangsa, tempat bermain, dan berlindung, dan mencari makan bagi burung pemakan buah, pemakan serangga, dan biji-bijian. Jenis pakan nektar dari vegetasi Hutan Rakyat merupakan salah satu jenis pakan yang dimanfaatkan oleh famili nectariniidae burung penghisap madu seperti dari jenis burung madu pengantin dan burung madu sriganti. Menurut Pergola, Dewi, dan Surya (2013), kondisi habitat sangat menentukan keberadaan burung, untuk mempertahankan kelangsungan hidupnya, oleh sebab itu apabila keadaan lingkungan kurang menguntungkan burung akan jarang atau tidak ada pada lingkungan tersebut, karena satwaliar memerlukan tempat-tempat yang dapat digunakan untuk mencari makan, tempat berlindung, beristirahat, dan berkembang biak (Alikodra, 1990).

\section{Status Lindung}

Pemberian status lindung merupakan upaya untuk mencegah terjadinya kepunahan sehingga dapat mempertahankan keberadaan jenis burung tersebut di alam. Keanekaragaman jenis burung merupakan indikator kondisi suatu habitat. Keberadaan burung sangat 
berpengaruh terhadap kondisi ekosistem tersebut dapat dikatakan baik atau tidak bagi makhluk hidup yang ada di dalamnya.

Berdasarkan hasil pengamatan yang telah dilakukan, terdapat 27 jenis burung yang berasal dari 16 famili. Beberapa jenis burung yang ditemukan di Hutan Rakyat Pekon Kelungu ini adalah jenis burung yang dilindungi menurut Peraturan Pemerintah Nomor 7 tahun 1999 Tentang Pengawetan Jenis Tumbuhan dan Satwa (Departemen Kehutanan, 1999). Burung-burung tersebut meliputi empat jenis burung yaitu madu dari famili Nectariniidae yaitu Madu pengantin (Nectarinia sperata) dan Madu Sriganti (Nectarinia jugularis). Dari famili Accipitridae yaitu Elang Hitam (Ictinaetus malayensis) dan Elang Bondol (Haliastur indus).

\section{KESIMPULAN}

Berdasarkan hasil penelitian di Pekon Kelungu Kecamatan Kotaagung Kabupaten Tanggamus pada bulan Juni 2015 ditemukan 27 spesies burung dengan jumlah individu 3018 yang berasal dari 16 famili. Nilai indeks keanekaragaman tertinggi yaitu $H^{\prime}=2.630$ terdapat pada stasiun dua di antara hutan rakyat dekat hutan lindung dan terendah yaitu $\mathrm{H}^{\prime}=1,701$ terdapat pada hutan rakyat dekat pemukiman, nilai indeks keanekaragaman tersebut tergolong dalam keanekaragaman sedang. Nilai indeks kesamarataan $\mathbf{J}_{1}=0,578, \mathbf{J}_{2}=0,817$ dan $\mathbf{J}_{3}$ $=0,801$, yang berarti $\mathbf{J}_{1}$ labil, $\mathbf{J}_{2}$ dan $\mathbf{J}_{3}$ stabil. Nilai indeks kesamaan spesies antar habitat (PC I dan II = 0,773), (PC I dan III = 0,773) tergolong kategori tinggi, (PC II dan III = 1) kategori sangat tinggi.

\section{DAFTAR PUSTAKA}

Alikodra, H. S. 1990. Pengelolaan Satwa Liar Jilid I. Buku. Institut pertanian Bogor. Bogor. $239 \mathrm{p}$.

Bibby, C., D. B. Neil dan H. David. 2004. Bird Census Techniques. Book. The Cambridge University Press. UK. 255 p.

Brower, J. E., H. Z Jerrold dan C. N. Von Ende. 1990. Field And Laboratory Method For General Ecology. Book. Wm. C. Brown Publisher. America. 273 p.

Darmawan, M. P. 2006. Keanekaragaman jenis burung pada beberapa tipe habitat di Hutan Lindung Gunung Lumut Kalimantan Timur. Skripsi. Institut Pertanian Bogor. Bogor. $138 \mathrm{p}$.

Departemen Kehutanan. 1999. Peraturan Pemerintah nomor 7 tahun 1999 tentang Pengawetan Jenis Tumbuhan dan Satwa. Buku. Kementrian Kehutanan. Jakarta. 44 p.

Fachrul, M. F. 2007. Metode Sampling Bioekologi. Buku. Bumi Aksara. Jakarta. 198 p.

Firdaus, A. B., A. Setiawan dan E. L. Rustiati. 2014. Keanekaragaman Spesies Burung di Repong Damar Pekon Pahmungan Kecamatan Pesisir Tengah Krui Kabupaten Lampung Barat. Jurnal Sylva Lestari. 2(2): 1-6.

Handari, A. 2012. Keanekaragaman jenis burung di hutan produksi Desa Gunung Sangkaran Kecamatan Blambangan Umpu Kabupaten Way Kanan. Skripsi. Universitas Lampung. Bandar Lampung. Tidak dipublikasikan. 60 p.

Holmes, D dan W. M. Rombang. 2001. Daerah Penting bagi Burung: Sumatera. Buku. PKA/BirdLife International-Indonesia Programme. Bogor. 338 p.

Indriyanto, 2006. Ekologi Hutan. Buku. Bumi Aksara. Jakarta. 210 p.

MacKinnon, J., K.Phillips. dan B. Van Balen. 1998. Burung-burung di Sumatera, Jawa, Bali dan Kalimantan. Buku. Departemen Kehutanan. Jakarta. 598 p. 
Martin. F., Harianto. S. P dan B. S. Dewi. 2012. Keanekaragaman jenis burung di pulau anak Krakatau Kawasan Cagar Alam Kepulauan Krakatau. Jurnal Sylva Lestari. 1: $13-14$.

Paerman, P. B. 2002. The Scale of Community Structure: Habitat Varition and Avian Guilds in The Tropical Forest. Journal Ecological Monographs. 72 (13):19-39.

Pergola, B., B. S. Dewi dan R. A. Surya. 2013. Keanekaragaman Jenis Burung di Lahan Basah Rawa Bujung Raman Desa Bujung Dewa Kecamatan Pagar Dewa Kabupaten Tulang Bawang Barat. Prosiding Seminar Nasional SATEK V. Universitas Lampung. Lampung.

Pergola, B. 2015. Peta lokasi penempatan titik pengamatan burung di Hutan Rakyat Pekon Kelungu Kecamatan Kotaagung Kabupaten Tanggamus. Tidak dipublikasikan.

Pamungkas, R. 2015. Keanekaragaman jenis burung di Kawasan Budidaya Desa Fajar Baru Kecamatan Pagelaran Utara Kabupaten Pringsewu. Skripsi. Universitas Lampung. Bandar Lampung. Tidak dipublikasikan. 67 p.

Ramdhani. Burung dan Dasar-Dasar Birdwatching. 2008. Diakses tanggal 29 September 2015. http://www.deriramdhani's.com.

Rohiyan, M., A. Setiawan dan E. L. Rustiati. 2014. Keanekaragaman Jenis Burung di Hutan Pinus dan Hutan Campuran Muarasipongi Kabupaten Mandailing Natal Sumatera Utara. Jurnal Sylva Lestari. 2 (2):8-98.

Setiawan, A., H. S. Alikodra., A. Gunawan dan D. Darneidi. 2006. Keanekaragaman Jenis Pohon Dan Burung D Beberapa Areal Hutan Kota Bandar Lampung. Jurnal Manajemen Hutan Tropika. 12 (1):1-13.

Simanjutak, E J., B. Nurdjali, dan S. Siahaan. 2013. Keanekaragaman Jenis Burung Diurnal di Perkebunan Kelapa Sawit PTPN XIII Desa Amboyo Inti Kecamatan Ngabang Kabupaten Landak . Jurnal Hutan Lestari. 1(13):317-326..

Solahudin, A. M. 2003. Keanekaragaman jenis burung air di Lebak Pampangan Kecamatan Pampangan Kabupaten Ogan Komering Ilir Sumatra Selatan. Skripsi. Jurusan Manajemen Hutan Fakultas Pertanian Universitas Lampung. Bandar lampung. Tidak dipublikasiakan. $63 \mathrm{p}$. 